\title{
Patient Satisfaction of Ambulatory Care Pharmacy Services in Pediatric and Maternity Hospital in Riyadh City, Saudi Arabia
}

\author{
Yousef Ahmed Alomi ${ }^{1 * *(D), ~ M a l i k a ~ A l s h a m a r i ², ~ H a w a z e n ~ A b d u l l a h ~ A l-K a m m a s h ~}{ }^{3}$, Aroub Alhamidi ${ }^{3}$, \\ Walaa Aboziad ${ }^{3}$, Kairat Imad Al-Hennawi ${ }^{3}$, Mohanad Imad Al-Hennawi ${ }^{3}$ \\ ${ }^{1}$ The Former General Manager of General Administration of Pharmaceutical Care, Former Head, National Clinical \\ Pharmacy and Pharmacy Practice, Former Head, Pharmacy R and D Administration, Ministry of Health, Riyadh, \\ SAUDI ARABIA. \\ ${ }^{2}$ Head, Pharmacy Services, Alyamama Hospital, Ministry of Health, Riyadh, SAUD ARABIA.
}

${ }^{3}$ Clinical Pharmacist Staff, General Administration of Pharmaceutical Care, Ministry of Health, Riyadh, SAUDI ARABIA.

\begin{abstract}
Objective: The ambulatory pharmacy practice is a crucial part of the healthcare system that delivers pharmaceutical care to the patients who are not admitted to the hospital. The aim of the study to explore the patient satisfaction of ambulatory care pharmacy services in Pediatrics and Maternity Hospital in Riyadh, Saudi Arabia. Methods: This is a 4-month cross-sectional survey of patient satisfaction of ambulatory care pharmacy services in Pediatrics and Maternity Hospital, Saudi Arabia. The survey consisted of forty-eight (48) questions divided into two parts: the first part collects demographic information and the second part contains questions on 11 domains: (1) medication availability, (2) patient counseling, (3) pharmacist and patient relationship, (4) medication reconciliation, (5) medication aberrance, (6) pharmacy location, (7) pharmacy waiting area, (8) pharmacy communications, (9) pharmacy waiting time, (10) pharmacy recommends to others, (11) overall patient satisfaction of pharmacy services. The survey was distributed to the hospitals in Riyadh city, included pediatrics and maternity hospitals ambulatory care patient. The survey was in an electronic format and it analyze the results through the Survey Monkey system. Results: A total of 237 patients responded to the survey. Out of 237 patients, 217 (91.6\%) was Saudi and 20 (8.4\%) was non-Saudi. There were 151 (63.7\%) female and $86(36.3 \%)$ male responders. Most of them were in age group of $18-44$ years (70\%) without any significant differences in the age groups among the hospitals. The highest level of education was high school 91 (38.4\%) followed by the Bachelor's degree 93 (39.2\%) and an intermediate school 44 (18.6\%). The mean [ \pm standard deviation (SD)] waiting time to get the medications was $13.6 \pm 4.75$ min. The average scores of domains $1,2,3,4,5,6,7,8,9$ and 10 were 3.11, 3.1, 3.61, 1.87, 1.72, 3.4, $2.77,1.93,3.68$ and 3.56 , respectively. With a total of $231(97.4 \%)$ responders, general evaluation of pharmacy services was found to be very good to excellent, whereas 228 (96.2\%) responders recommend the pharmacy to their family or friends and 224 (95.3\%) responders prefer to revisit pharmacy. Conclusion: More than two-thirds of the patients were pleased with ambulatory care pharmacy services at Riyadh, Saudi Arabia. Medication reconciliation, medication adherence and pharmacy waiting area domains were not found to be satisfied. Improving ambulatory care pharmacy services will avert drug misadventures, avoid additional cost and surge patient satisfaction with pharmacy services.

Key words: Ambulatory care, Ministry of Health, Patient, Pharmacy, Pediatrics, Satisfaction, Riyadh, Saudi Arabia.
\end{abstract}

Received: 13-11-2018;

Accepted: 17-01-2019

*Correspondence to:

Dr. Yousef Ahmed Alomi

The Former General Manager of General Administration of Pharmaceutical

Care, Former Head, National Clinical

Pharmacy and Pharmacy Practice,

Former Head, Pharmacy R and D

Administration, Ministry of Health, P.O.BOX 100, Riyadh 11392, Riyadh, SAUDI ARABIA.

Phone no: +966504417712

Email: yalomi@gmail.com

DOI: 10.5530/ijpcs.2019.8.22

Copyright: ๑ the author(s),publisher and licensee International Journal of Pharmacology and Clinical Sciences. This is an open-access article distributed under the terms of the Creative Commons Attribution Non-Commercial License, which permits unrestricted noncommercial use, distribution, and reproduction in any medium, provided the original work is properly cited.

This is an open access article distributed under the terms of the Creative Commons Attribution-NonCommercial-ShareAlike 4.0 License

Access this article online

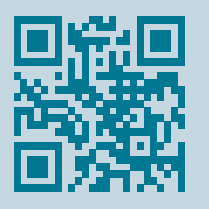

www.ijpcs.net 


\section{INTRODUCTION}

In recent years, there has been a growing prominence in health systems on the provision of ambulatory care pharmacy services. Payers have formed incentives to diminution hospitalization rates and length of stay, making way for a new shift toward pay-forperformance, outcome-based compensation and liable care. Ambulatory care pharmacists have the accountability to instruct and counsel the patient, evaluate the patient's need of medication, accomplish the patient's medication and progress a relationship with the patients and their families. ${ }^{[1]}$ The appropriate practice of pharmaceutical care in ambulatory care settings consequences in better outcomes both clinically and economically and improved practice mightto help more patients. Patient gratification of healthcare services including pharmaceutical care service is an essential tool to measure the healthcare strategic plan in Saudi Arabia. The mechanism has involved the patient in the decision of healthcare services and as part of transparently of work within the framework of Vision 2030. ${ }^{[1]}$ General Administration of Pharmaceutical Care at Ministry of Health in Saudi Arabia established a system of pharmacy patient's satisfaction in past years. ${ }^{[2]}$ Ambulatory pharmacy practice is a vital fragment of the healthcare system that delivers pharmaceutical care to the patients who are not admitted to the hospital. Ambulatory care pharmacists play an essential role in ambulatory health care system such as managing patients' medication, following up with patients and educating patients about medication side effects. ${ }^{[3]}$ A study published by Strand LM and his colleagues, enlightening ambulatory care pharmacy services have a direct impact on clinical and economic outcomes. The study also showed that proper practices result in increasing number of patients served and increased the time spent with each patient as well. [4] Therefore, it is vital to measure the quality of service provided by the ambulatory care pharmacists and one of the best indicators of excellence is to measure patient satisfaction. ${ }^{[5]}$ Ministry of health in Saudi Arabia considered patients' satisfaction is an integral part of the standard assessment and required it for any follow-up assessment. ${ }^{[6]}$

Few studies reported regarding patients' satisfaction of pharmaceutical care services have been conducted in entire Saudi Arabia. ${ }^{[7-10]}$ Alomi YA et al. stated on patient satisfaction of pharmaceutical care primary care centers in 2016. ${ }^{[10]}$ However, most of the studies conducted in the community sector, primary care centers, ENT hospital, public and general hospital only.
Also, the sociocultural inconsistency might disturb the outcomes disparagingly with international studies. ${ }^{[1-14]}$ In this study, we will emphasis on determining the patient satisfaction level in ambulatory care pharmacy in Riyadh, Saudi Arabia. There are very few studies performed to validate patient satisfaction in the region of Riyadh at pediatrics and maternity ambulatory pharmacy services of the $\mathrm{MOH}$ hospitals or any non-MOH governmental and private hospitals in the Kingdom of Saudi Arabia. Therefore, we intended to explore the patient satisfaction at pediatrics and maternity ambulatory care services at Riyadh city in Saudi Arabia.

\section{MATERIALS AND METHODS}

This is a 4-month cross-sectional survey of patient satisfaction of ambulatory care pharmacy services in Pediatrics and Maternity Hospital, Saudi Arabia. The survey consisted of 48 questions divided into two parts: the first part collects demographic information and the second part contains questions on 11 domains (1) medication availability, (2) patient counseling, (3) pharmacist and patient relationship, (4) medication reconciliation, (5) medication aberrance, (6) pharmacy location, (7) pharmacy waiting area, (8) pharmacy communications, (9) pharmacy waiting time, (10) pharmacy recommends to others, (11) overall patient satisfaction of pharmacy services. We used the 5-point Likert response scale system to acquire responses. There were close-ended questions. The survey was distributed to the hospitals in Riyadh city, included pediatrics and maternity hospital type. The public hospital consisted of 250 beds, which will be stretched in the future. This hospital has been accredited by the Central Board for Accreditation of Healthcare Institutions at Saudi Arabia. The hospital has emergency care and ambulatory care services with 250 beds meant for pediatrics and maternity, with specialized devices catering to the inpatients, for instance, critical care, obstetrics and gynecology, pediatrics, medical pediatrics and pediatric nephrology. The hospital has pharmaceutical care department that caters 24/7. The pharmacy consists of emergency, inpatient and ambulatory pharmacy services. The hospital's pharmacy distributes the medications through unit dose system and a computerized physician order system is followed 24/7. The pharmacy delivers very comprehensive Total Parenteral Nutrition (TPN) services for neonatal patients, drug information services, medication safety services and total quality management services. The hospital consists of great emergency services and neonatal critical care services for adults and 
pediatrics. It has ambulatory care clinic and inpatient wards for adults' surgical and medical requirements. The authors interviewed the patients with an electronic survey documentation. The study was distributed in an electronic format and the data were analyzed through Survey Monkey system.

\section{RESULTS}

A total of 237 patients responded to the survey. Out of 237 patients, 217 (91.6\%) was Saudi and 20 (8.4\%) was non-Saudi. There were 151 (63.7\%) female and 86 (36.3\%) male responders. Most of them were in age group of 18-44 years (70\%) without any significant differences in the age groups among the hospitals. The highest level of education was high school 91 (38.4\%) followed by the Bachelor's degree 93 (39.2\%) and an intermediate school 44 (18.6\%). Most of the patients visited the pharmacy 3 to 4 times in the past 12 months 118 (49.8\%) with 192 (81.7\%) follow-up visit, whereas the others 43 (18.3\%) visited the pharmacy for the first time. Most of the patients visited the pharmacy on morning duty 160 (67.5\%) while $77(32.5 \%)$ appeared the pharmacy at evening duty. The mean $[ \pm$ Standard Deviation (SD)] waiting time to get the medications was $13.6 \pm 4.75 \mathrm{~min}$ (Table 1). The average scores of domains $1,2,3,4,5,6,7,8,9$ and 10 were $3.11,3.1$, $3.61,1.87,1.72,3.4,2.77,1.93,3.68,3.56$, respectively (Table 2 and 3 ). With a total of 231 (97.4\%) responders, general evaluation of pharmacy services was found to be very good to excellent, whereas $228(96.2 \%)$ responders recommend the pharmacy to their family or friends and 224 (95.3\%) responders prefer to revisit pharmacy. Most of the patients were satisfied with pharmacy services 139 (58.6\%), whereas the others were neither satisfied nor happy with pharmacy services 90 (38\%) (Table 4 and 5).

\section{DISCUSSION}

In this study, we evaluated the patients' view about pharmaceutical care in ambulatory care services for four months in the city of Riyadh, Saudi Arabia. The number of responders in all the hospitals was nearly parallel to the number of responders in other studies. ${ }^{[5,9,12,13]}$ Most of the patients were Saudi nationals, which was predictable because only a small proportion of non-Saudi residents are allowable to receive healthcare services from governmental sectors. There was a small variance in the male to female ratio, which is nearly unimportant. Most of the patients were in

\section{Table 1: Demographic responder qualifications} information.

Response

Count

Response

Percent

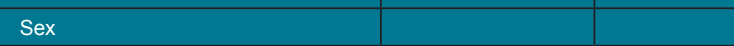

\begin{tabular}{|l|c|c|}
\hline Female & 151 & $63.7 \%$ \\
\hline Male & 86 & $36.3 \%$ \\
\hline Answered question & 237 & \\
\hline Skipped question & 0 & \\
\hline Nationality & & $91.6 \%$ \\
\hline Saudi & 217 & $8.4 \%$ \\
\hline Non-Saudi & 20 & \\
\hline Answered question & 237 & \\
\hline Skipped question & 0 & $5.1 \%$ \\
\hline Age & 12 & $31.2 \%$ \\
\hline$<18$ & 74 & $38.8 \%$ \\
\hline $18-29$ & 92 & $24.9 \%$ \\
\hline $30-44$ & 59 & $0.0 \%$ \\
\hline $45-59$ & 0 & \\
\hline $60+$ & 237 & \\
\hline Answered question & 0 & Response Percent \\
\hline Skipped question & Response Count & \\
\hline Type of visit & 43 & $18.3 \%$ \\
\hline
\end{tabular}

\begin{tabular}{|l|c|c|}
\hline First visit & 43 & $18.3 \%$ \\
\hline Follow up & 192 & $81.7 \%$ \\
\hline Answered question & 235 & \\
\hline Skipped question & 2 & \\
\hline $\begin{array}{l}\text { In the last 12 months, the number of } \\
\text { times visited the pharmacy }\end{array}$ & Response Count & Response Percent \\
\hline
\end{tabular}

\begin{tabular}{|c|c|c|}
\hline None & 0 & $0.0 \%$ \\
\hline 1 time & 47 & $19.8 \%$ \\
\hline 2 & 31 & $13.1 \%$ \\
\hline 3 & 60 & $25.3 \%$ \\
\hline 4 & 58 & $24.5 \%$ \\
\hline 5 to 9 & 38 & $16.0 \%$ \\
\hline 10 or more times & 3 & $1.3 \%$ \\
\hline Answered question & 237 & \\
\hline Skipped question & 0 & \\
\hline Time of Visiting the Pharmacy & Response Count & Response Percent \\
\hline Morning & 160 & $67.5 \%$ \\
\hline Evening & 77 & $32.5 \%$ \\
\hline Night & 0 & $0.0 \%$ \\
\hline Answered question & 237 & \\
\hline Skipped question & 0 & \\
\hline $\begin{array}{l}\text { Average waiting time to get the } \\
\text { medications }\end{array}$ & $\begin{array}{l}\text { Mean +/-SD } \\
\text { (minute) }\end{array}$ & \\
\hline $\begin{array}{l}\text { Ambulatory care pharmacy of } \\
\text { Pediatrics and Maternity Hospital }\end{array}$ & $13.6+/-4.75$ & \\
\hline Answered question & 236 & \\
\hline Skipped question & 1 & \\
\hline Level of Education & Response Count & Response Percent \\
\hline Doctorate degree & 0 & $0.0 \%$ \\
\hline Master degree & 2 & $0.8 \%$ \\
\hline Bachelor Degree & 93 & $39.2 \%$ \\
\hline Diploma & 1 & $0.4 \%$ \\
\hline High school & 91 & $38.4 \%$ \\
\hline Intermediate School & 44 & $18.6 \%$ \\
\hline Primary School & 6 & $2.5 \%$ \\
\hline Not educated & 0 & $0.0 \%$ \\
\hline Answered question & 237 & \\
\hline Skipped question & 0 & \\
\hline
\end{tabular}




\begin{tabular}{|c|c|c|c|c|c|c|c|}
\hline Answer Options & $\begin{array}{l}\text { Very } \\
\text { poor }\end{array}$ & Poor & Good & $\begin{array}{l}\text { Very } \\
\text { good }\end{array}$ & Excellent & $\begin{array}{l}\text { Rating } \\
\text { Average }\end{array}$ & $\begin{array}{l}\text { Response } \\
\text { Count }\end{array}$ \\
\hline \multicolumn{8}{|l|}{ 1. Medication Availability Domain } \\
\hline Have you received all the medications, that has been prescribed to you & 0 & 34 & 66 & 104 & 32 & 3.57 & 236 \\
\hline $\begin{array}{l}\text { You have received a prescription refill of your medicines to continue } \\
\text { dispensing from pharmacy directly next months. }\end{array}$ & 3 & 105 & 101 & 24 & 3 & 2.66 & 236 \\
\hline \multicolumn{8}{|l|}{ 2. Patient Counselling Domain } \\
\hline All medications you received were packed. & 0 & 0 & 9 & 187 & 40 & 4.13 & 236 \\
\hline Instructions were labeled on each medication & 0 & 0 & 5 & 172 & 60 & 4.23 & 237 \\
\hline $\begin{array}{l}\text { Instructions that contain of: (patient's name, medication's name, } \\
\text { medication's strength and how to use) were written clearly. }\end{array}$ & 0 & 1 & 60 & 128 & 47 & 3.94 & 236 \\
\hline $\begin{array}{l}\text { The pharmacist provides you written/ or printed information about drug } \\
\text { therapy and/or diseases. }\end{array}$ & 7 & 219 & 8 & 2 & 1 & 2.03 & 237 \\
\hline The pharmacist Explains to you how to know if medications are working & 56 & 144 & 35 & 1 & 0 & 1.92 & 236 \\
\hline The pharmacist explains all the possible side effects & 53 & 129 & 55 & 0 & 0 & 2.01 & 237 \\
\hline $\begin{array}{l}\text { The pharmacist provides you information about the proper storage of } \\
\text { your medication. }\end{array}$ & 74 & 84 & 76 & 3 & 0 & 2.03 & 237 \\
\hline $\begin{array}{l}\text { The pharmacist provides you with thorough medication counseling and } \\
\text { encourages you to ask questions. }\end{array}$ & 0 & 11 & 122 & 87 & 17 & 3.46 & 237 \\
\hline You understand what pharmacist saying & 0 & 0 & 26 & 138 & 73 & 4.20 & 237 \\
\hline \multicolumn{7}{|l|}{ answered question } & 237 \\
\hline \multicolumn{7}{|l|}{ skipped question } & 0 \\
\hline
\end{tabular}

\begin{tabular}{|c|c|c|c|c|c|c|c|}
\hline Answer Options & $\begin{array}{l}\text { Very } \\
\text { poor }\end{array}$ & Poor & Good & $\begin{array}{l}\text { Very } \\
\text { good }\end{array}$ & Excellent & $\begin{array}{l}\text { Rating } \\
\text { Average }\end{array}$ & $\begin{array}{l}\text { Response } \\
\text { Count }\end{array}$ \\
\hline \multicolumn{8}{|l|}{ 3. Pharmacist and Patient Relationship Domain } \\
\hline $\begin{array}{l}\text { When you're receiving your prescription medications, the } \\
\text { pharmacist delivers your medicines in a polite way }\end{array}$ & 0 & 0 & 70 & 146 & 21 & 3.79 & 237 \\
\hline $\begin{array}{l}\text { Pharmacists have technical skills (thoroughness, carefulness, } \\
\text { competence). }\end{array}$ & 0 & 1 & 74 & 149 & 12 & 3.73 & 236 \\
\hline All pharmacists characterized with courtesy and respect. & 1 & 34 & 128 & 69 & 5 & 3.18 & 237 \\
\hline The way the pharmacist answers your questions excellent. & 0 & 0 & 71 & 159 & 7 & 3.73 & 237 \\
\hline The amount of time the pharmacist spends with you. & 0 & 2 & 91 & 137 & 7 & 3.63 & 237 \\
\hline \multicolumn{8}{|l|}{ 4. Medication Reconciliation Domain } \\
\hline $\begin{array}{l}\text { Pharmacist uses information about you previous conditions/ } \\
\text { drugs when assessing your drug therapy. }\end{array}$ & 14 & 214 & 6 & 0 & 1 & 1.98 & 235 \\
\hline $\begin{array}{l}\text { You have received a copy of prescription contains all } \\
\text { medications prescribed to you and may use during outpatient }\end{array}$ & 59 & 176 & 1 & 1 & 0 & 1.76 & 237 \\
\hline \multicolumn{8}{|l|}{ 5. Medication Adherence Domain } \\
\hline the pharmacist ask about medication compliance & 70 & 155 & 10 & 2 & 0 & 1.76 & 237 \\
\hline $\begin{array}{l}\text { Did the pharmacist follow up you and call you after taking your } \\
\text { medications as prescribed }\end{array}$ & 79 & 155 & 1 & 1 & 0 & 1.68 & 236 \\
\hline \multicolumn{7}{|l|}{ answered question } & 237 \\
\hline skipped question & & & & & & & 0 \\
\hline
\end{tabular}

middle aged (30-44 years), which is the normal age for their activities and usually more education. most of the continuing diseases, whereas the smallest number of patients was elderly; this may be because of Waiting time is one of the most vital aspects regarding the low acquiescence of elderly patients with respect to patient consummation; this area was found to be 


\begin{tabular}{|c|c|c|c|c|c|c|c|}
\hline Answer Options & $\begin{array}{l}\text { Very } \\
\text { poor }\end{array}$ & Poor & Good & $\begin{array}{l}\text { Very } \\
\text { good }\end{array}$ & Excellent & $\begin{array}{l}\text { Rating } \\
\text { Average }\end{array}$ & $\begin{array}{l}\text { Response } \\
\text { Count }\end{array}$ \\
\hline \multicolumn{8}{|l|}{ 6. Pharmacy Location Domain } \\
\hline The pharmacy conveniently located & 0 & 39 & 75 & 112 & 11 & 3.40 & 237 \\
\hline \multicolumn{8}{|l|}{ 7. Pharmacy Waiting Area Domain } \\
\hline $\begin{array}{l}\text { The waiting area of pharmacy comfortable, convenient } \\
\text { pharmacy lounge? }\end{array}$ & 102 & 62 & 58 & 15 & 0 & 1.94 & 237 \\
\hline $\begin{array}{l}\text { The amount of time you have been waiting before seeing a } \\
\text { pharmacist was }\end{array}$ & 0 & 3 & 91 & 140 & 3 & 3.60 & 237 \\
\hline The place of pharmaceutical counseling respects your privacy. & 1 & 1 & 24 & 178 & 33 & 4.02 & 237 \\
\hline \multicolumn{8}{|l|}{ 8. Pharmacy Communication Domain } \\
\hline Getting through to the pharmacy by phone & 15 & 176 & 1 & 0 & 0 & 1.93 & 192 \\
\hline \multicolumn{8}{|l|}{ 9. Pharmacy Waiting Time Domain } \\
\hline $\begin{array}{l}\text { The amount of time it takes to get a prescription filled at your } \\
\text { pharmacy. }\end{array}$ & 0 & 3 & 77 & 150 & 7 & 3.68 & 237 \\
\hline \multicolumn{8}{|l|}{ 10. Pharmacy Recommended to other patients Domain } \\
\hline $\begin{array}{l}\text { Do you recommend your family and friends to visit the } \\
\text { pharmacy? }\end{array}$ & 0 & 7 & 93 & 135 & 2 & 3.56 & 237 \\
\hline \multicolumn{8}{|l|}{$\begin{array}{l}\text { 11. Overall Patient Satisfaction of Pharmacy Services } \\
\text { Domain }\end{array}$} \\
\hline Your general evaluation for the pharmaceutical care & 0 & 2 & 88 & 143 & 4 & 3.63 & 237 \\
\hline $\begin{array}{l}\text { Prefer to visit the pharmacy again or recommend to your } \\
\text { brothers or friends }\end{array}$ & 1 & 8 & 121 & 103 & 2 & 3.41 & 235 \\
\hline \multicolumn{7}{|l|}{ answered question } & 237 \\
\hline \multicolumn{7}{|l|}{ skipped question } & 0 \\
\hline
\end{tabular}

Table 5: Overall, satisfied or dissatisfied with your last visit to our pharmacy.

\begin{tabular}{|l|c|c|}
\hline Answer Options & $\begin{array}{c}\text { Response } \\
\text { Count }\end{array}$ & $\begin{array}{c}\text { Response } \\
\text { Percent }\end{array}$ \\
\hline Very satisfied & 4 & $1.7 \%$ \\
\hline Somewhat satisfied & 139 & $58.6 \%$ \\
\hline Neither satisfied nor dissatisfied & 90 & $38.0 \%$ \\
\hline Somewhat dissatisfied & 4 & $1.7 \%$ \\
\hline Very dissatisfied & 0 & $0.0 \%$ \\
\hline Answered question & 237 & \\
\hline Skipped question & 0 & \\
\hline
\end{tabular}

substantial among the hospitals, which is related to the differences in the distribution of the organization system and the number of pharmacy staff at each hospital. The waiting time was found to be satisfactory as most of the patients preferred to get their medications in less than 30 mins; comparable results were obtained by another study conducted in Singapore. ${ }^{[14]}$ Regarding medication accessibility, our results were found to be less noteworthy than that stated in a previous study conducted in a primary healthcare center in Saudi Arabia. This alteration might be because of the small size of primary healthcare center in the previous study. ${ }^{[12]}$ As a result, it is easier to check if the pharmacy requires a new lot of certain medicines. Despite being the high rating of pharmacy therapy, there was a low level of satisfaction in areas like elucidation the side effects and storing of the medication and their medication information; however, our results are still in the range of those reported in the literature and are better than the study conducted in an African country and the range of other international studies. ${ }^{[5,10,12]}$ The results regarding pharmacy's affiliation and patient satisfaction were equally good and similar in our study, but the results were less than those reported in a nationwide study conducted in the primary healthcare centers. Because the number of people in ambulatory care pharmacies is greater than that in the primary healthcare centers and therefore, less time disbursed with each patient. In the medication reconciliation area, our results were found to be not satisfactory because this service is not maintained at all hospitals and pharmacies yet. The results on pharmacy location, waiting area and waiting time were found to be decent as described in the literature. Moreover, most of the patients stated their preparedness to acclaim the pharmacy to their friends and family and they were mostly pleased with the pharmaceutical services. ${ }^{[5,8,9,12,15]}$ Our results were found to be barely improved than those reported in the literature, which is related to different pharmacy services among the cities in various study. The results on patient satisfaction were not found to be suggestively different among the hospitals. ${ }^{[5,9,10,12]}$ This study was conducted 
first in Riyadh city and several mislaid points need to be discovered at all the hospitals.

\section{CONCLUSION}

Although patient fulfilment of pediatrics and maternity ambulatory care pharmacy services surpasses more than two-thirds of the responders, there were several domains that need to be enhanced to reach an ideal level of patient satisfaction. More than two-thirds of the patients were pleased with ambulatory care pharmacy services at Riyadh, Saudi Arabia. This means medication reconciliation, medication adherence and pharmacy waiting area domains need additional enhancement. Improving pediatrics and maternity ambulatory care pharmacy services will avert drug misadventures, avoid additional cost and surge patient satisfaction with pharmacy services.

\section{ACKNOWLEDGEMENT}

None.

\section{CONFLICT OF INTEREST}

The authors declare no conflict of interest.

\section{ABBREVIATIONS}

MEs: Medication Errors; MOH: Ministry of Health; TPN: Total Parental Nutrition; KSA: Kingdom of Saudi Arabia.

\section{ORCID ID}

Yousef Ahmed Alomi (D, https://orcid.org/0000-00031381-628X

\section{REFERENCES}

1. Government of Saudi Arabia. Saudi Arabia Vision 2030. 2016 Available from: https://vision2030.gov.sa/sites/default/files/report/Saudi Vision2030_EN_2017.pdf

2. Ministry of Health. Healthcare Strategic Plan 2010-2020. 2012.

3. Ambulatory Care Pharmacy. Board of Pharmacy Specialties. Available from: https://www.bpsweb.org/bps-specialties/ambulatory-care/

4. Strand LM, Cipolle RJ, Morley PC, Frakes MJ. The impact of pharmaceutical care practice on the practitioner and the patient in the ambulatory practice setting: twenty-five years of experience. Curr Pharm Des. 2004;10(31):3987-4001.

5. Surur AS, Teni FS, Girmay G, Moges E, Tesfa M, Abraha M. Satisfaction of clients with the services of an outpatient pharmacy at a university hospital in northwestern Ethiopia: A cross-sectional study. BMC Health Serv Res. 2015;15(1):229.

6. Alomi YA, Alghamdi SJ, Alattyh RA. Strategic Plan of General Administration of Pharmaceutical Care at Ministry of Health in Saudi Arabia 2012-2022. J Pharm Pharm Scien. 2015;1(13):1-8.

7. Al-Arifi MN. Patients' perception, views and satisfaction with pharmacists role as health care provider in community pharmacy setting at Riyadh, Saudi Arabia. Saudi Pharm J. 2012;20(4):323-30.

8. Al-Jumah KA, Hassali MA, Al-Zaagi I. Adaptation and validation of a questionnaire assessing patient satisfaction with pharmacy services in general hospitals. Patient Prefer Adherence. 2014;8:371-5.

9. Al-Jumah KA, Hassali MA, Alzaagi I. Patient Satisfaction with the Health Services Provided by the Pharmacist at a General Hospital in Riyadh, Saudi Arabia. Eur J Pers Centered Health. 2014;2(4):517.

10. Alomi YA, Kurdy L, Aljarad Z, Basudan H, Almekwar B. Patient satisfaction of pharmaceutical care of primary care centers at Ministry of Health in Saudi Arabia. J Pharm Pract Community Med. 2016;2(3):79-87.

11. Abolfotouh MA, Al-Assiri MH, Alshahrani RT, Almutairi ZM, Hijazi RA, Alaskar AS. Predictors of patient satisfaction in an emergency care centre in central Saudi Arabia: a prospective study. Emerg Med J. 2017;34(1):27-33

12. Oparah AC, Kikanme LC. Consumer satisfaction with community pharmacies in Warri, Nigeria. Res Soc Adm Pharm. 2006;2(4):499-511.

13. Holsclaw SL, Olson KL, Hornak R, Denham AM. Assessment of patient satisfaction with telephone and mail interventions provided by a clinical pharmacy cardiac risk reduction service. J Manag Care Pharm. 2005;11(5):403-9.

14. Tam VHY, Lim MM. Patients' perceptions and expectations of outpatient pharmacy services in a teaching hospital. Int J Pharm Pract. 1997;5(3):128-32.

15. Alturki M, Khan TM. A study investigating the level of satisfaction with the health services provided by the Pharmacist at ENT hospital, Eastern Region Alahsah, Kingdom of Saudi Arabia. Saudi Pharm J. 2013;21(3):255-60.

Cite this article as: Alomi YA, Alshamari M, Al-Kammash HA, Alhamidi A, Al-Hennawi KI, Aboziad W, Al-Hennawi MMI. Patient Satisfaction of Ambulatory Care Pharmacy Services in Pediatric and Maternity Hospital in Riyadh City, Saudi Arabia. Int J Pharmacol. Clin. Sci. 2019;8(2):129-34. 